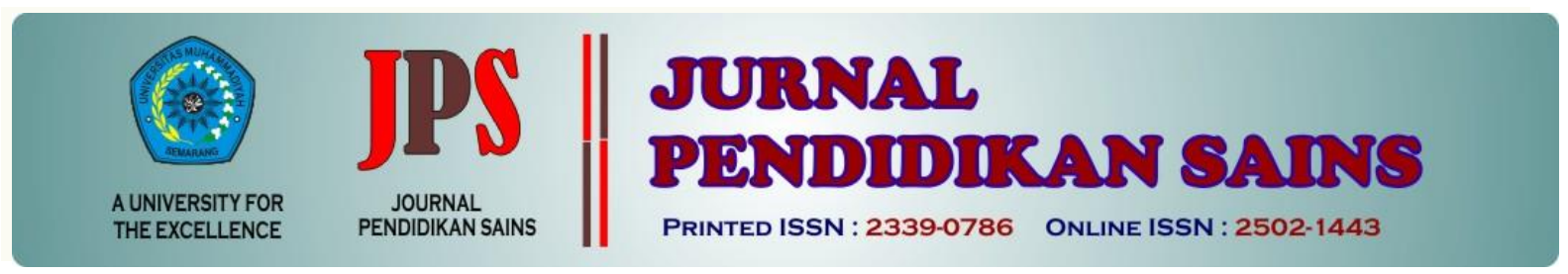

http://jurnal.unimus.ac.id/index.php/JPKIMIA

\title{
PENANAMAN SIKAP PRO-LINGKUNGAN MELALUI PENGEMBANGAN DESA WISATA "KAMPOENG KALEN" DI DUSUN DANEN
}

\author{
Oleh: \\ Ayu Rahayu ${ }^{1}$, Eko Yuliyanto ${ }^{2}$ \\ ${ }^{1}$ Universitas Sarjanawiyata Tamansiswa \\ ayurahayu.indonesia@gmail.com \\ ${ }^{2}$ Universitas Muhammadiyah Semarang \\ ekoyuliyanto@unimus.ac.id
}

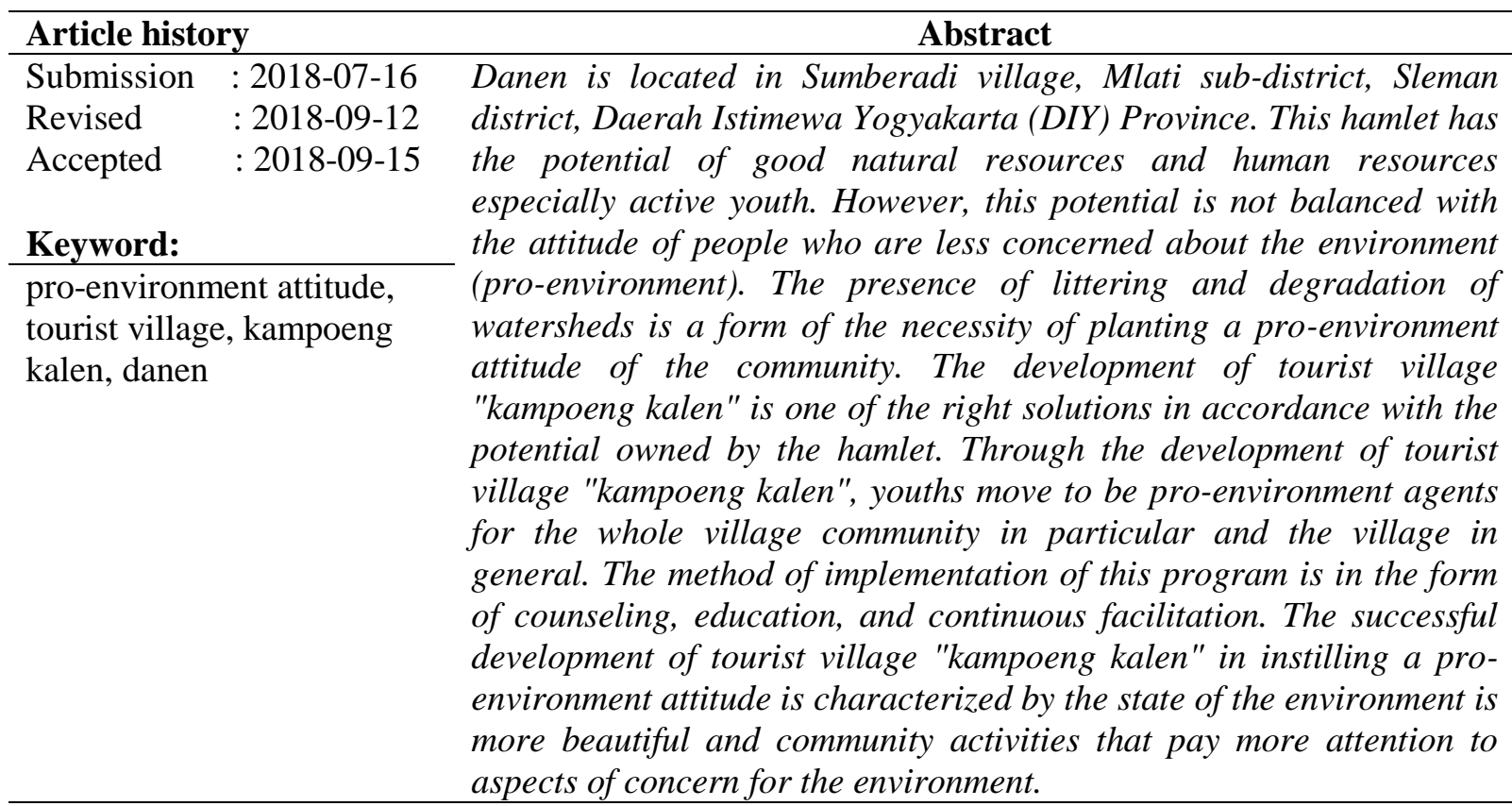

\section{Pendahuluan}

Dusun Danen memiliki berbagai potensi baik alam mapupun sumber daya manusia. Dusun ini terletak di desa Sumberadi, kecamatan Mlati, kabupaten Sleman, Provinsi Daerah Istimewa Yogyakarta (DIY). Jarak dusun Danen dengan ibukota kecamatan Mlati sekitar

*Corresponding Author:

Nama : Ayu Rahayu

Lembaga : Universitas Sarjanawiyata Tamansiswa

Email : ayurahayu.indonesia@gmail.com
$1 \mathrm{~km}$, jarak ke ibu kota kabupaten Sleman sekitar $5 \mathrm{~km}$, dan jarak ke ibukota provinsi DIY sekitar $20 \mathrm{~km}$. Penduduk dusun Danen terdiri dari 120 kepala keluarga (KK) atau sekitar 460 jiwa. Mata pencaharian masyarakat dusun Danen sebagian besar adalah sebagai petani. 


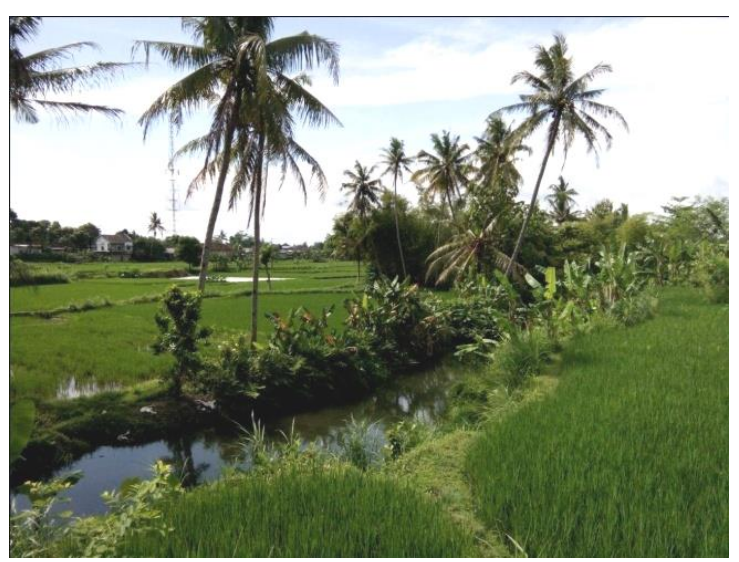

Gambar 1. Pemandangan persawahan dan sungai alami serta saluran irigasi di Dusun

\section{Danen}

Pemuda di dusun Danen aktif dalam komunitas dengan kegiatan yang positif seperti karang taruna yang diberi nama Gerakan Muda-mudi Danen (GMD), serta kelompok kerohanian yaitu Remaja Masjid Al Furqon (REMAF). GMD adalah kelompok pemuda dengan berbagai kegiatan organisasi kemasyarakatan di dusun Danen. Sedangkan REMAF merupakan kelompok yang melaksanakan kegiatan edukasi kepada anak-anak usia dini khususnya dalam bidang keagamaan.

Selain potensi sumber daya manusia khususnya pemuda, dusun ini memiliki potensi sumber daya alam berupa pemandangan wilayah dusun yang masih asri, areal persawahan, aliran sungai alami, aliran sungai irigasi, berbagai vegetasi tanaman pertanian, budidaya perikanan. dan berbagai potensi wisata alam. Namun, potensi yang bagus di dusun Danen ini belum diolah dengan optimal. Berdasarkan hasil observasi di beberapa lokasi yang ada di dusun Danen terdapat beberapa gelaja kerusakan alam terutama di daerah aliran sungai.

Kerusakan DAS berupa pendangkalan aliran sungai. disebabkan oleh penebangan vegetasi pohon bambu yang berlebihan sehingga menyebabkan longsornya daerah sekitar DAS serta menumpuknya sedimentasi Selain disebabkan oleh penebangan vegetasi, sedimentasi juga disebabkan oleh pembuangan sampah secara sembarangan oleh warga.

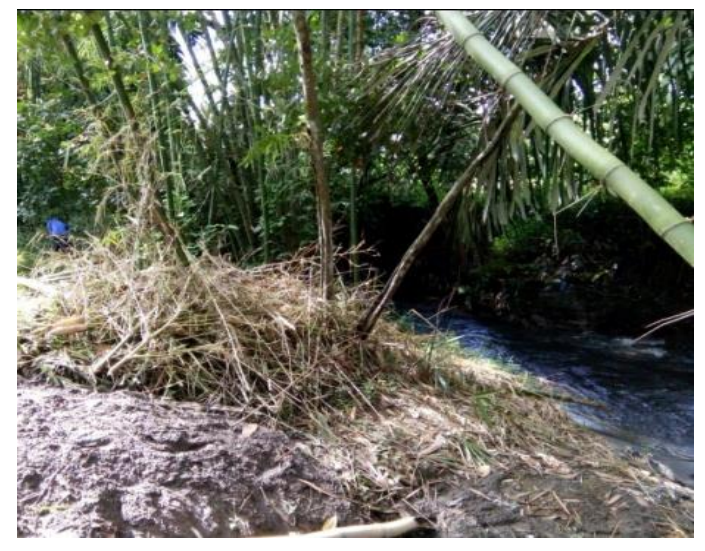

Gambar 1a). Penebangan vegetasi

di DAS

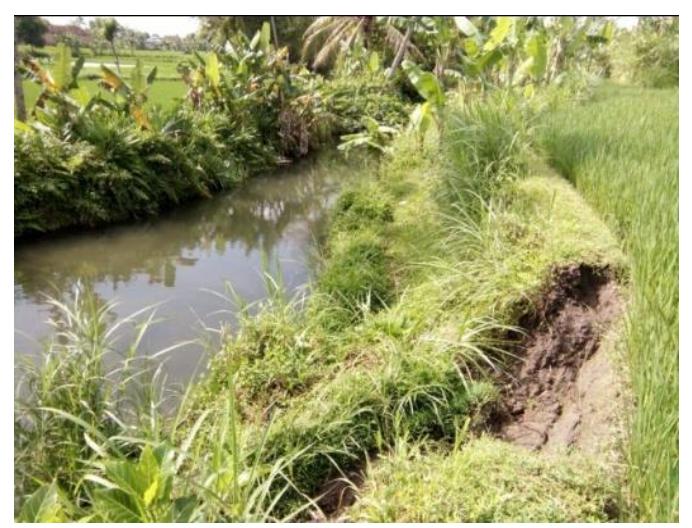

Gambar 1b). DAS longsor

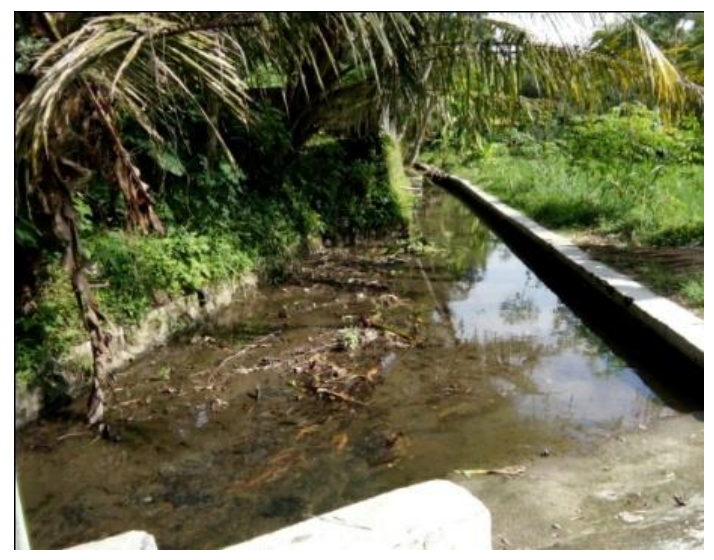

Gambar 1c). Pendangkalan DAS 


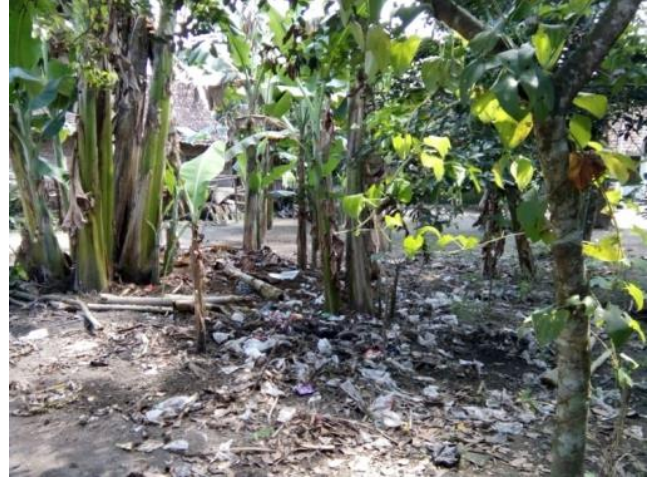

$$
\begin{array}{r}
\text { Gamabar 1d). Pembuangan sampah } \\
\text { sembarangan oleh warga }
\end{array}
$$

Pada tahun 2014, GMD membuat icon dusun dengan nama "Danen Green Village". Para pemuda mencita-citakan sebuah dusun yang lestari dengan berbagai potensi alam yang dimiliki. Namun icon tersebut masih sebatas simbol yang belum mencerminkan keadaan dusun dengan beberapa kerusakan lingkungan seperti pendangkalan DAS, banjir saat hujan deras, dan sampah yang masih banyak berserakan di lingkungan dusun. Kegiatan yang dilaksanakan warga juga belum sesuai dengan konsep konservasi karena kurangnya pemahaman warga tentang konsep prolingkungan.

Permasalahan-permasalahan yang ada di dusun Danen tersebut membutuhkan penanganan dengan perlakuan khusus. Salah satu hal yang dapat dilakukan yaitu menggunakan adalah pemberdayaan masyarakat dengan tujuan untuk menanamkan konsep pro-lingkungan. Pemberdayaan masyarakat disini berarti masyarakat tidak hanya sebagai objek tetapi juga subjek atau pelaku (Attar Muhammad, dkk, 2013: 9). Pemberdayaan masyarakat yang berhasil akan membentuk masyarakat yang mandiri, yaitu masyarakat yang mampu memikirkan, memutuskan, dan melakukan sesuatu yang dipandang tepat dalam mencapai pemecahan masalah yang dihadapi (Kesi Widjajanti, 2011: 16). Program pemberdayaan masyarakat dapat dilaksanakan dalam bentuk konservasi lingkungan, pendidikan, dan ekonomi sesuai dengan potensi yang dimiliki.

Berdasarkan potensi yang dimiliki dusun Danen, maka pembentukan desa wisata adalah salah satu bentuk pemberdayaan masyarakat yang tepat dalam mewujudkan masyarakat yang pro-lingkungan. Sikap prolingkungan atau environmental attitude adalah berbagai tindakan yang berorientasi pada kepedulian terhadap alam. Apa saja yang dilakukan harus mempertimbangkan dampak positif dan negatif utamanya terhadap alam. Sikap pro-lingkungan terdiri dari tiga macam, yaitu pada tingkat individu, sosial, dan ekologi (Schultz, P., \& Zelezny, L., 1999). Hal ini sejalan dengan pendapat Kaiser, F. G., Wölfing, S., \& Fuhrer, U. (1999: 7) bahwa sikap pro-lingkungan terdiri dari kepedulian terhadap alam dan proses sosial di dalamnya. Proses sosial ini dapat berupa kepedulian terhadap manusia lain serta kepedulian terhadap hewan dan tumbuhan yang ada di sekitarnya.

Sikap pro-lingkungan dapat ditanamkan melalui berbagai hal, salah satunya adalah melalui pariwisata (Powell, R. B., \& Ham, S. H., 2008: 467; Chiu, Y. T. H., Lee, W. I., \& Chen, T. H., 2014: 321; Beaumont, N.: 2001). Buckley (1994: 661) menyatakan bahwa hubungan antara pariwisata dan lingkungan adalah: (1) komponen lingkungan alam merupakan sebuah daya tarik pariwisata, (2) pengelolaan wisata yang baik dapat meminimalisir dampak negatif lingkungan, (3) barang-barang cenderamata memberikan kontribusi terhadap konservasi, dan (4) sikap peduli lingkungan wisatawan dapat dipengaruhi melalui pengelolaan wisata.

Pembentukan desa wisata akan mengaitkan konservasi lingkungan melalui pendidikan sehingga dapat menaikkan ekonomi masyarakat. Konsep pokok desa wisata yaitu pelestarian, pendidikan, pariwisata, perekonomian, dan peran serta masyarakat, Pariwisata ini merupakan pariwisata agraris yang berkelanjutan. Pariwisata berkelanjutan adalah pariwisata yang memenuhi kebutuhan masa sekarang dan masa mendatang serta tidak merusak alam, 
budaya masyarakat setempat agar dapat diwariskan pada generasi penerus. Desa wisata merupakan jenis wisata yang mendukung upaya konservasi. Wisata ini juga memberikan apresiasi yang tinggi terhadap lingkungan, budaya, sejarah dan partisipasi penduduk lokal (Imam Rudy Kurnianto, 2008).

$$
\text { Pengembangan desa wisata }
$$

membutuhkan partisipasi dan peran aktif masyarakat. Namun berdasarkan studi yang ada sebelumnya, seringkali masyarakat kurang dapat berperan aktif dalam pengembangan wisata dikarenakan oleh berbagai hal misalnya minimnya pengetahuan tentang ekowisata (Damayanti, E., 2014; Raharjana, D. T., 2012; Dewi, M. H. U., 2013). Oleh karena itu diperlukan agen pro-lingkungan yang akan mewujudkan kehidupan masyarakat dusun Danen lebih pro-lingkungan. Agen inilah berasal dari kelompok pemuda dusun Danen yang terdiri dari: karang taruna atau Gerakan Muda-Mudi Danen (GMD) dan Remaja Masid Al-Furqon (REMAF). Pada tahun 2014, GMD merancang sebuah program dalam rangka mewujudkan desa pro-lingkungan dengan icon "Danen Green Village". REMAF dengan retin melaksanakan kegiatan edukasi kepada anakanak usia dini khususnya dalam bidang keagamaan. Sudah adanya pergerakan para generasi muda, menunjukkan adanya potensi untuk diintegrasikan ke dalam pengembangan desa wisata. Potensi ini menjadi pijakan utama pemuda dan masyarakat memiliki sikap prolingkungan.

Atas inisiatif para pemuda, desa wisata yang akan dikembangkan dusun Danen diberi nama "Kampoeng Kalen". Hal tersebut didasarkan atas potensi utama dusun atau "kampoeng" Danen, yaitu adanya aliran sungai alami di sekeliling dusun serta aliran irigasi atau dalam bahasa Jawa (bahasa penduduk lokal) adalah "kalen". Dalam makalah ini dipaparkan bagaimana pengembangan desa wisata "Kampoeng Kalen" sehingga dapat menanamkan sikap pro-lingkungan masyarakat.

\section{Metode Penelitian}

Kegiatan dilaksanakan mulai bulan Februari sampai dengan Juli tahun 2018 di dusun Danen. Metode pelaksanaan progam yaitu dengan penyuluhan, edukasi, dan pendampingan berkelanjutan. Berdasarkan permasalahan yang ada, kemudian dicari alternative solusinya seperti pada Tabel 1 . Penyuluhan dilaksanakan dalam bentuk sosialisi kegitan dan pendampingan oleh orang di luar dusun yang lebih ahli. Edukasi dilakukan kepada para pemuda dan anakanak sebagai agen pro-lingkungan yang nantinya menjadi contoh bagi seluruh masyarakat. Pendampingan terhadap program dilakukan secara kontinu dan berkelanjutan untuk mengawal kegiatan dapat berlangsung dengan lancar dan mendiskusikan solusi jika ada permasalahan. Analisa data dilakukan dengan membandingkan keadaan sebelum dan sesudah adanya kegiatan pengembangan desa wisata.

Tabel 1. Metode pelaksanaan kegiatan

\begin{tabular}{|c|c|c|}
\hline No & Permasalahan & Metode Pelaksanaan \\
\hline 1. & $\begin{array}{l}\text { Paradigma masyarakat dengan } \\
\text { konsep pro-lingkungan } \& \text { desa } \\
\text { ekowisata masih rendah; }\end{array}$ & $\begin{array}{l}\text { Mengumpulkan seluruh anggota karang taruna } \\
\text { (GMD dan REMAF dusun Danen serta } \\
\text { memberi penyuluhan peran pemuda dalam } \\
\text { pengembangan dan memajukan desa. }\end{array}$ \\
\hline 2. & $\begin{array}{l}\text { Penerapan pendidikan pro- } \\
\text { lingkungan di kalangan } \\
\text { masyarakat dan generasi muda } \\
\text { belum optimal. }\end{array}$ & $\begin{array}{l}\text { a. Edukasi anak-anak usia dini melalui kegiatan } \\
\text { TPA (REMAF) } \\
\text { b. Edukasi tentang pengolahan sampah pada } \\
\text { GMD }\end{array}$ \\
\hline
\end{tabular}




\begin{tabular}{lll}
\hline No & Permasalahan & Metode Pelaksanaan \\
\hline 3 & Belum adanya integrasi wisata & a. Pembentukan Pokdarwis \\
& $\begin{array}{l}\text { alam dan potensi masyarakat yang } \\
\text { ada di dusun Danen. }\end{array}$ & b. Pembuatan sarana Desa Wisata \\
\hline
\end{tabular}

Hasil Penelitian dan Pembahasan Penyuluhan Peran Pemuda dalam Pengembangan dan Memajukan Desa

Kegiatan penyuluhan dilaksanakan

di bulan Februari, sebagai awal dari rangkaian kegiatan dalam program pemberdayaan masyarakat ini. Kegitan penyuluhan dibagi menjadi dua tahapan yaitu: (1) Sosialisasi potensi desa dan penyamaan persepsi tentang pengembangan desa melalui ekowisata, serta (2) Pendampingan pembentukan desa wisata yang dibersamai fasilitator desa wisata tingkat nasional.

Sosialisasi potensi desa dan penyamaan persepsi tentang pengembangan desa melalui ekowisata dilaksanakan pada hari Sabtu tanggal 17 Februari 2018 pukul 19.30 WIB sampai dengan selesai. Kegiatan dilaksanakan di Gedung UPP "Guyup Rukun" Danen yang dibangun secara swadaya oleh masyarakat untuk berbagai macam keperluan dusun. Peserta kegiatan ini adalah para pemuda dusun Danen yang terdiri dari GMD dan REMAF, para pemangku jabatan seperti kepala desa, kepala dusun, ketua RW, dan ketua RT. Jumlah peserta yang hadir yaitu 23 orang.

Kegiatan berlangsung dengan lancar. Dalam kegiatan tersebut disampaikan bahwa ekowisata memiliki dampak positif yang sangat banyak. Dusun Danen memiliki potensi sumber daya alam yang dapat dikembangkan Perlu peran masyarakat sembagai sumber daya manusia untuk mengembangkan potensi yang dimiliki ini. Jika dusun Danen dapat dikembangkan menjadi desa wisata maka akan banyak dampak yang diperoleh misalnya lingkungan yang lebih asri dan pemasukan ekonomi bagi warga menjadi lebih baik.

Pendampingan pembentukan desa wisata yang dibersamai fasilitator desa wisata tingkat nasional dilaksanakan pada hari Ahad tanggal 20 Maret 2018 pukul 09.00 WIB s.d. selesai di Gedung UPP "Guyup Rukun" Danen. Pembicara utama adalah Aris Widianto selaku fasilitator desa wisata tingkat nasional. Materi yang disampaikan berjudul "Pengembangan Potensi Desa Wisata Menjadi Daya Tarik Wisata/ Desa Wisata Berbasis Komunitas Masyarakat (Community Base Tourism)". Pesera kegiatan yaitu Kepala Desa, perangkat desa, kepala dukuh, ketua RW, ketua RT, perwakilan karang taruna dusun lain, Kelompok Wanita Tani, Kelompok Mina Padi (3 orang), dan Kelompok Ternak Ayam. Peserta kegiatan ini adalah berbagai kalangan pemangku jabatan, pemuda desa, dan penggerak organisasi kemasyarakatan.

$$
\text { Setelah pemaparan materi }
$$

pendampingan, kegiatan dilanjutkan dengan kunjungn lapangan. Fasilitator dan para peserta kegiatan melihat potensi yang dimiliki dusun Danen seperti area persawahan, sungai, dan tambak ikan untuk selanjutnya didiskusikan potensi utama yang akan dikembangkan dusun. Setelah kegiatan ini berlangsung, para pemuda sangat termotivasi dalam mengembangkan desanya. Mereka mulai merencanakan bagaimana memulai mengembangkan desa melalui ekowisata. 


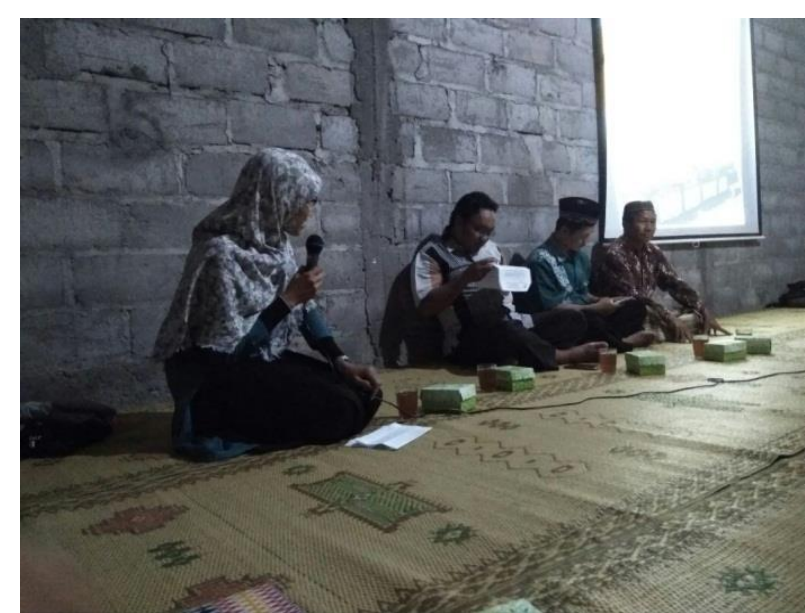

2a) Tim pengabdi bersama perangkat desa

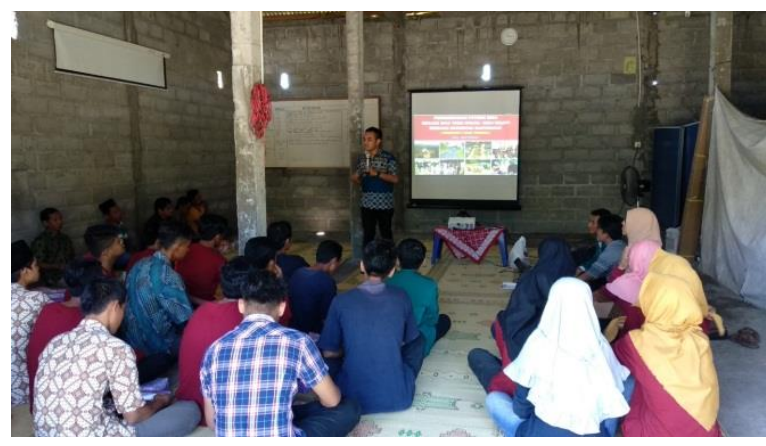

2c) Peserta antusias mengikuti kegiatan pendampingan oleh fasilitator

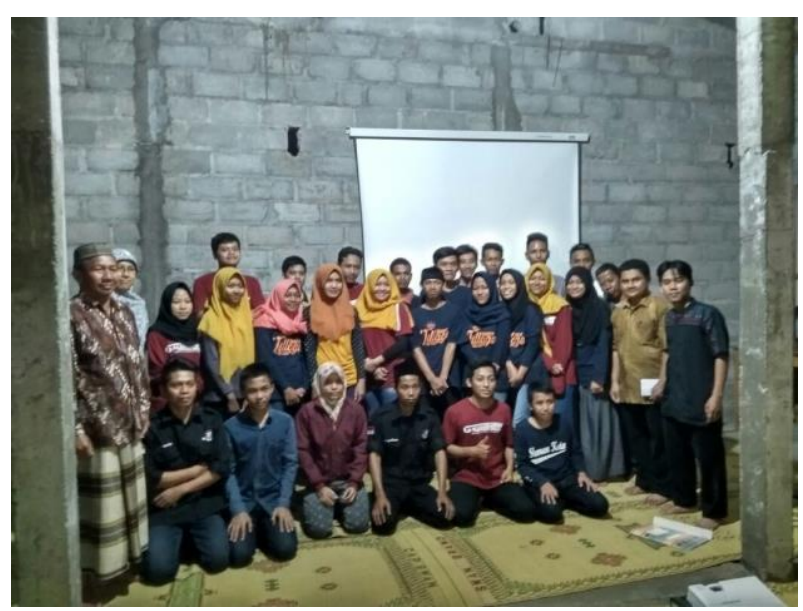

b) Peserta kegiatan sosialisasi

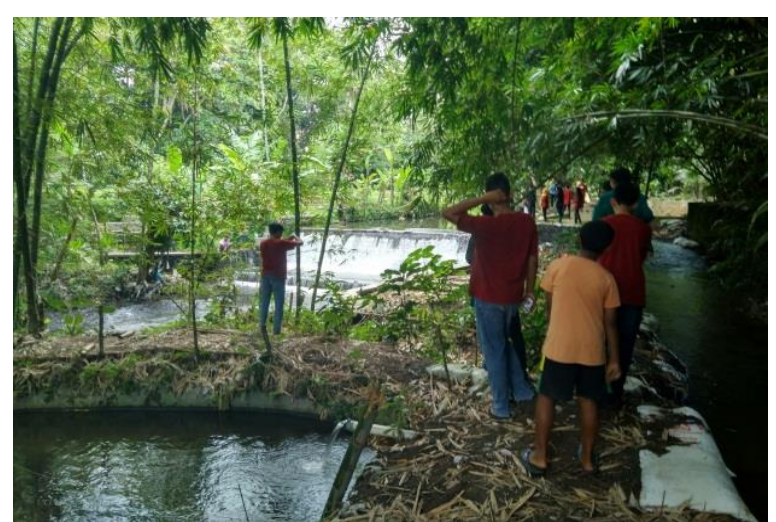

2d) Observasi potensi sungai dan minapadi

Gambar 2. Kegiatan penyuluhan peran pemuda dalam mengembangkan desa

\section{Edukasi tentang Pengolahan Sampah pada GMD}

Salah satu permasalahan utama sebuah masyarakat adalah pengelolaan sampah. Termasuk di dusun Danen, sampah organik belum dimanfaatkan secara maksimal (Gambar 3.a). Melalui peran pemuda GMD, sampah organik diolah dan dimanfaatkan menjadi pupuk kompos
(Gambar 3b, 3c, dan 3d). Kegiatan pengolahansampah organic ini dilakukan secara bersama-sama pada hari Ahad tanggal 27 Maret 2018. Setelah itu, pada Ahad, 24 Mei 2018, sampah organik yang telah menjadi kompos dimanfaatkan untuk menanam tanaman yang akan menghiasi sekeliling dusun (Gambar 3e dan 3f). 


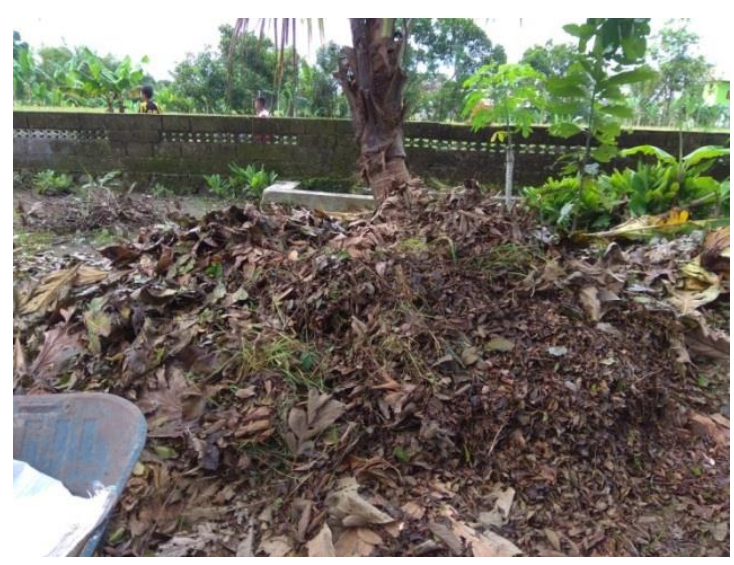

3a) Potensi sampah organik yang belum dimanfaatkan

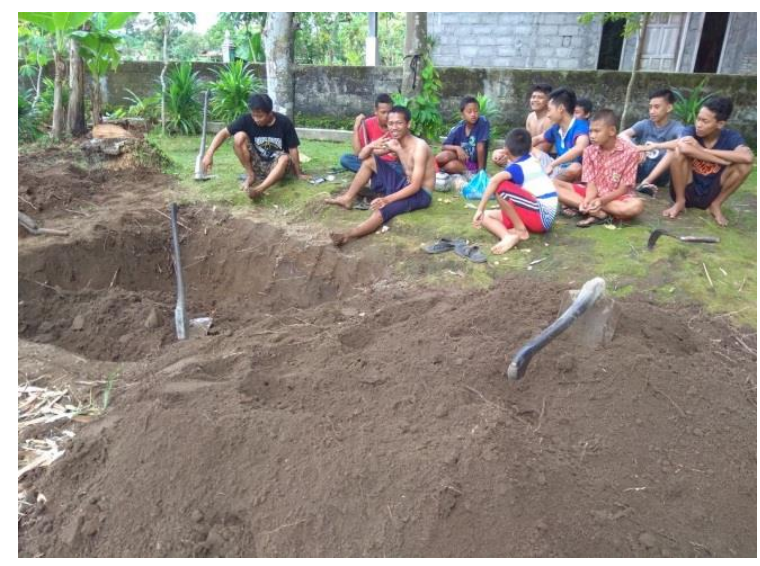

3c) Pembuatan "blumbang” untuk membuat pupuk organik

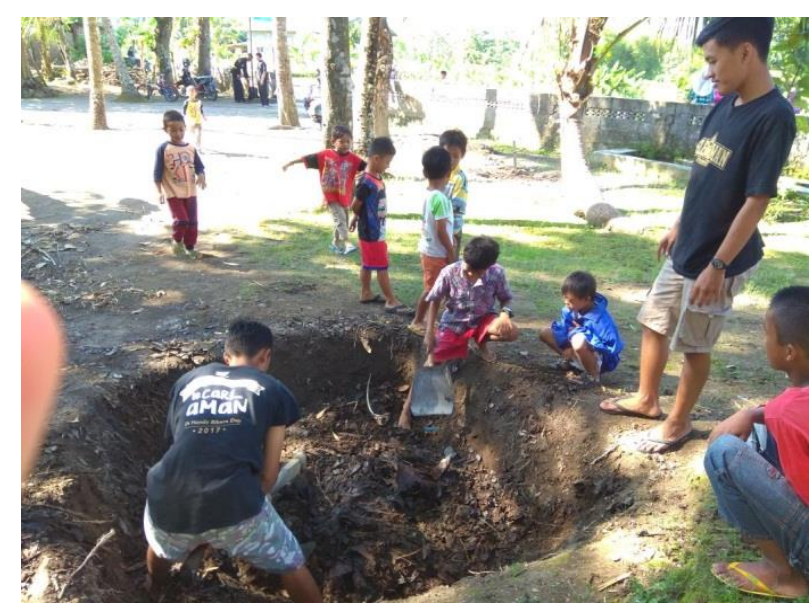

3e) Pengambilan pupuk organik

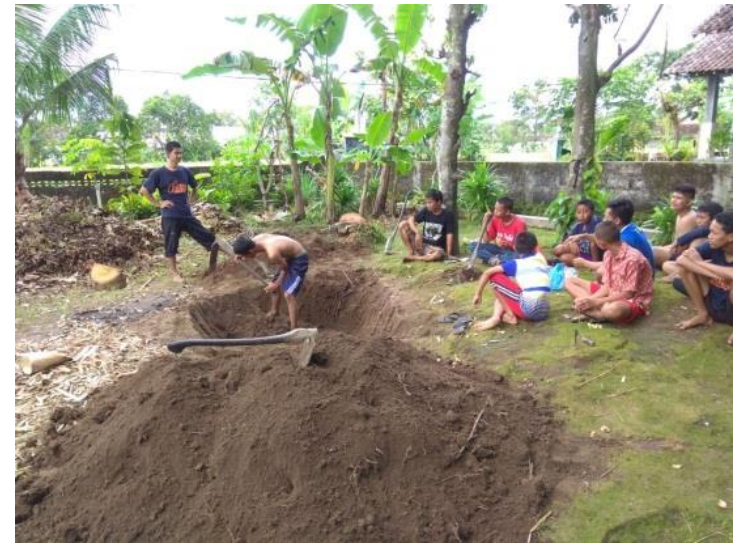

3b) Pembuatan "blumbang" untuk membuat pupuk organik

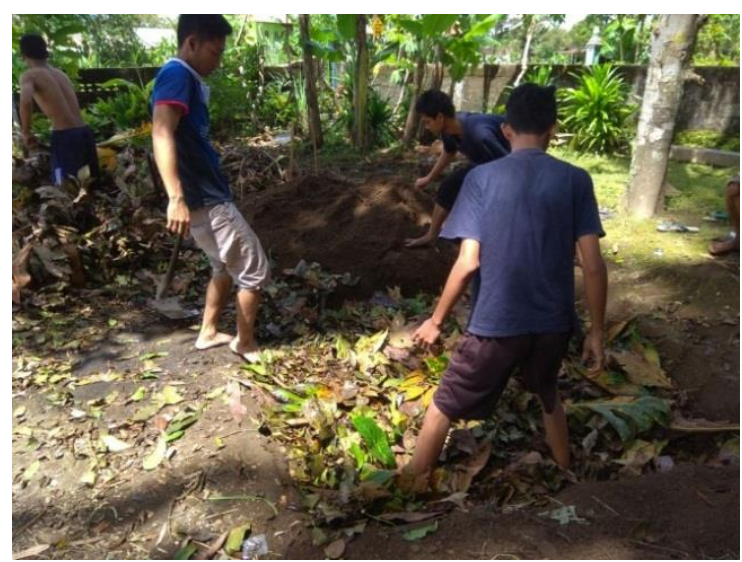

3d) Memasukkan sampah organik ke dalam "blumbang"

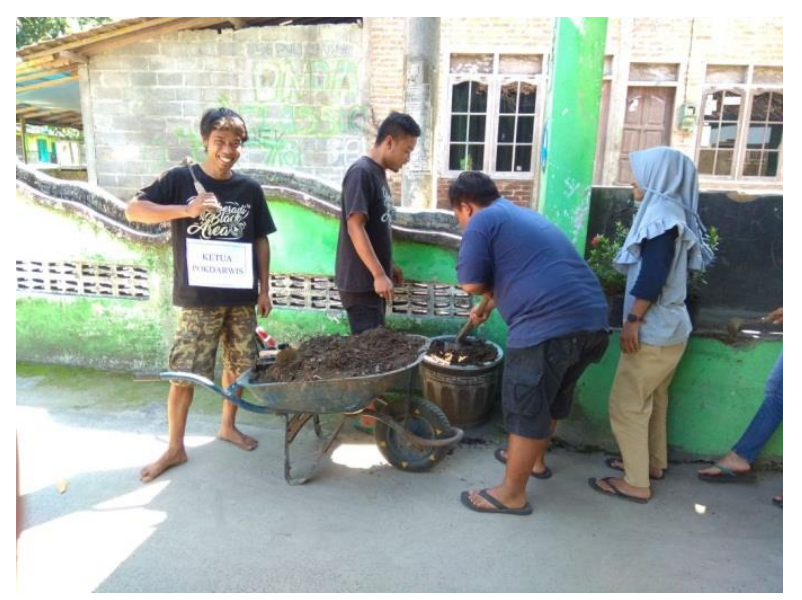

3f) Menempatkan pupuk organik

dalam pot besar

Gambar 3. Edukasi pengolahan sampah organik

Edukasi Anak-Anak Usia Dini Dlam Kegiatan TPA (REMAF)

Kegiatan edukasi anak-anak usia dini dilakukan secara kontinu melalui TPA (Taman Pendidikan Al Quran) di Masjid Al
Furqon (masjid yang berada di tengah dusun dan sering digunakan warga untuk berbagai kegiatan keagamaan). Melalui kegiatan TPA, kepedulian terhadap lingkungan ditanamkan untuk anak usia 
dini. Hal ini ditandai dengan terlibatnya anak-anak usia dini dalam kegiatan pengembangan desa seperti penataan lingkungan desa dan penanaman tanaman di sekeliling dusun.

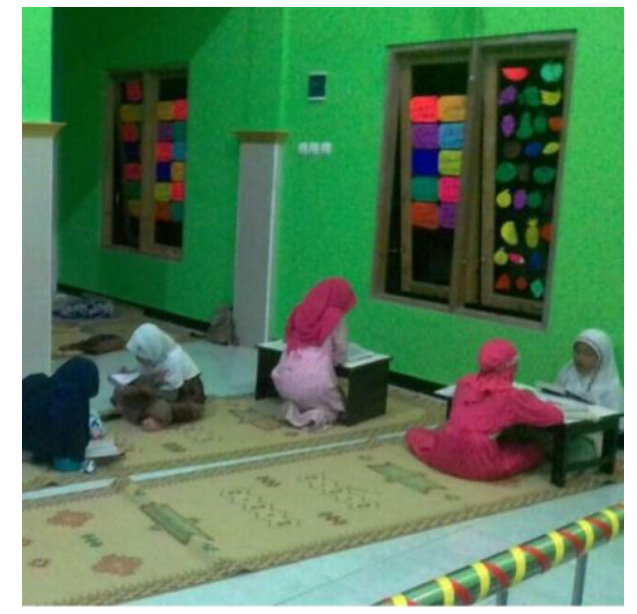

3a) Pelaksanaan TPA untuk anak usia dini

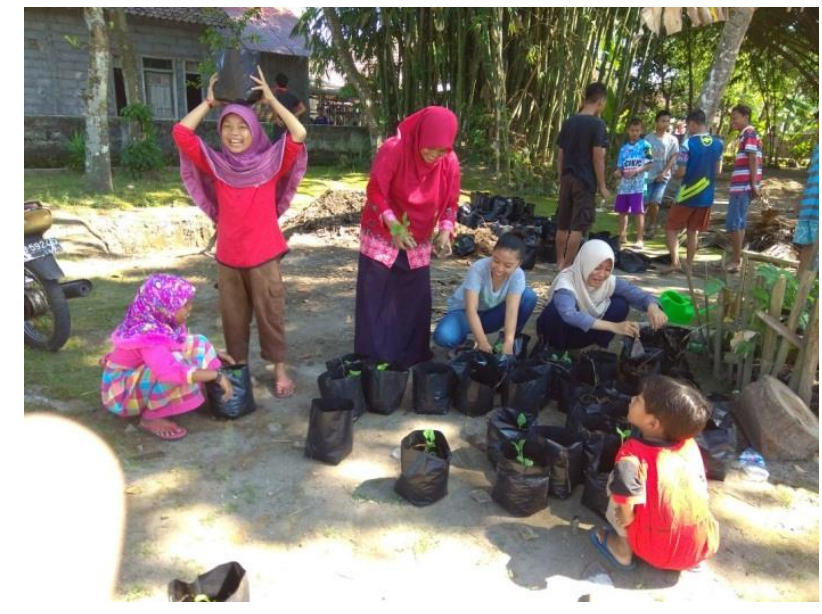

3b) Anak-anak menanam tanaman sebagai bentuk kepedulian lingkungan

Gambar 3. Edukasi anak usia dini yang tergabung dalam TPA

\section{Pembentukan Pokdarwis}

Pengembangan desa wisata memiliki ujung tombak pada pembentukan Pokdarwis (kelompok Sadar Wisata). Keberadaan Pokdarwis ini sesuai dengan UU No.40 Tahun 2009 Pasal 13 dimana pemerintah daerah bertanggungjawab melaksanakan penyadaran, pemberdayaan, dan pengembangan potensi pemuda berdasarkan kewenangan dan tanggung jawabnya sesuai dengan karakteristik dan potensi daerah masing-masing.

Dusun Danen telah memiliki kepengurusan Pokdarwis yang terdiri dari Pembina, penasihat, ketua, wakil ketua , bendahara, sekretaris, humas dan pemasaran, serta berbagai sie. Sie yang ada yaitu sie obyek wisata/daya tarik, sie kuliner \& souvenir, sie akomodasi, sie pemandu wisata, sie atraksi/budaya, sie bidang kesehatan/keamanan, dan sie kebersihan.

\section{Pembuatan Sarana Desa Wisata}

Sarana desa wisata adalah salah satu aspek yang paling penting dalam pengembangan desa wisata. Sarana desa wisata dikembangkan mulai bulan Februari hingga saat ini dan akan terus dikembangkan secara bertahap untuk kedepannya. Pengembangan sarana wisata harus mempertimbangkan kebutuhan lapangan dan kepedulian lingkungan. Gambar 4 menunjukan berbagai aktivitas pembuatan sarana desa wisata kampoeng kalen. 


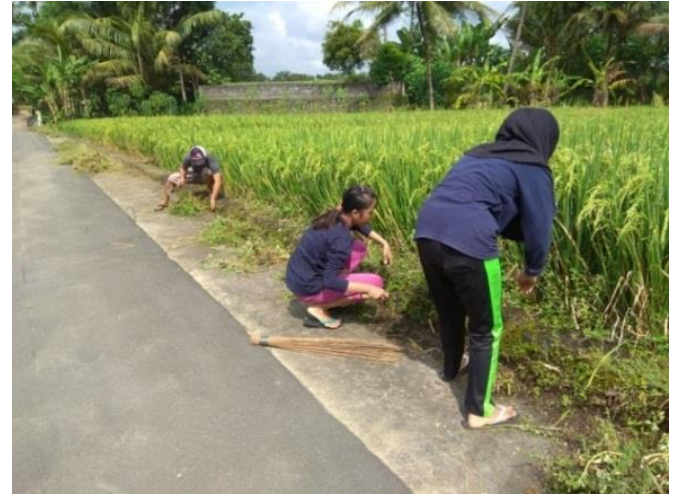

4a) Bersih-bersih di sekitar jalan persawahan

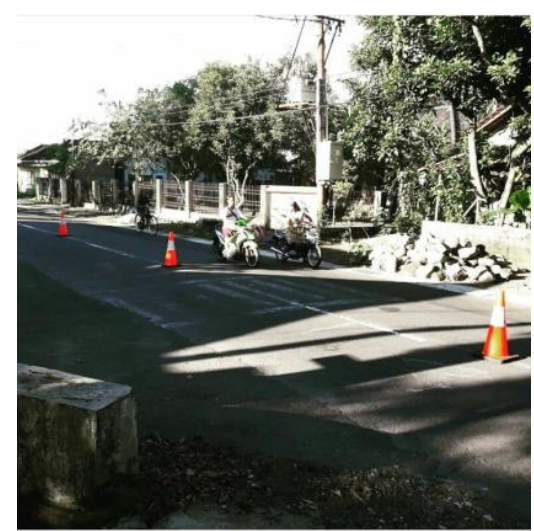

4c) Membuat pembatas jalan lalu lintas

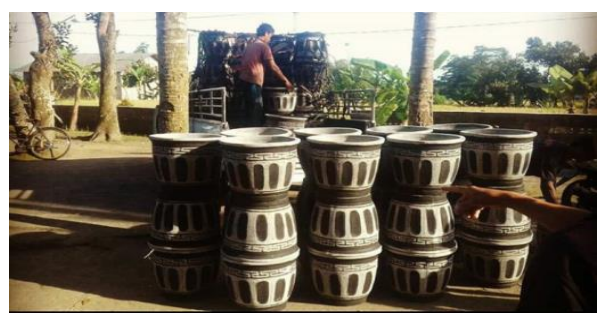

4e) Penyiapan pot bunga

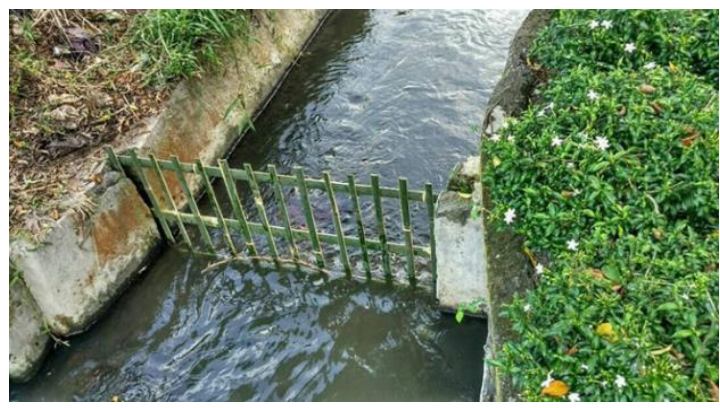

4g) Pemasangan jaring sampah

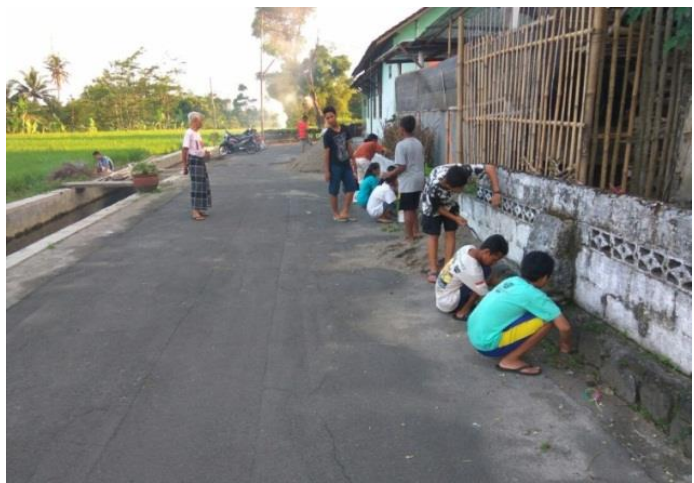

4b) Bersih-bersih di sekitar jalan utama dusun

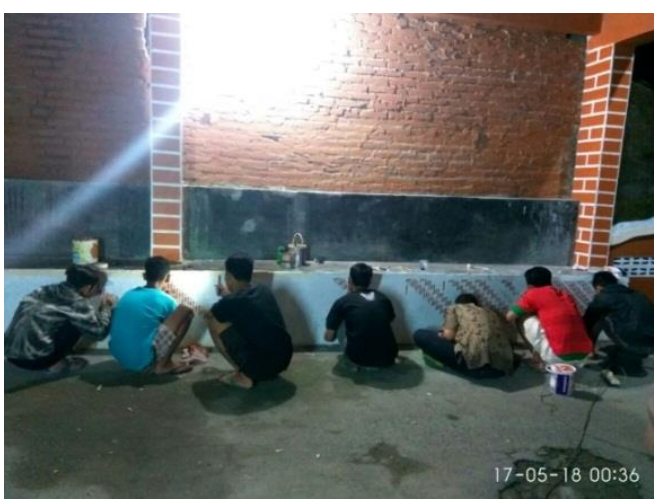

4d) Mengecat gapura

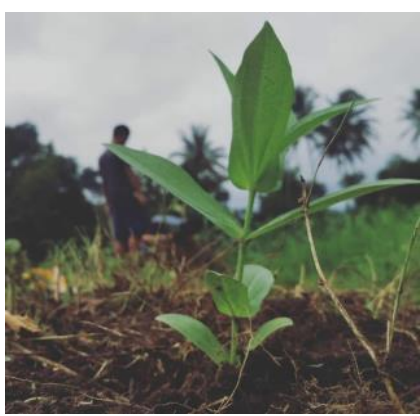

4f)Menanam tanaman hias

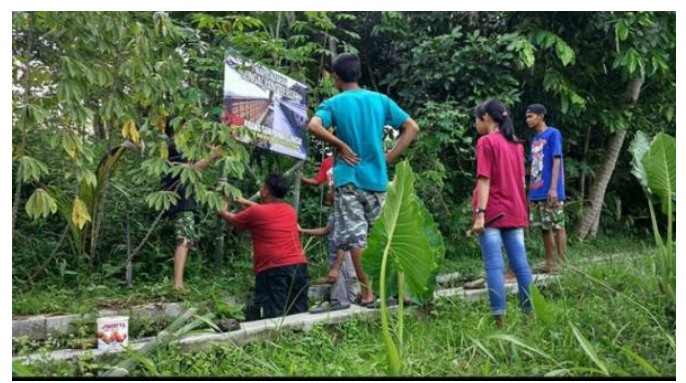

4h) Pemasangan banner peduli lingkungan

Gambar 4. Proses pembuatan sarana desa wisata

\section{Kondisi Dusun Danen Melalui Pengembangan Desa Wisata "Kampoeng Kalen"}


Desa wisata "Kampoeng Kalen" lingkungan, sikap pro-lingkungan masih terus dikembangkan dengan partisipasi masyarakat. Masyarakat sangat antusias dalam memajukan desanya. Melalui kegiatan yang berwawasan masyarakat akan semakin baik. Kondisi fisik dusun Danen sampai saat ini tergambar pada Gambar 5.

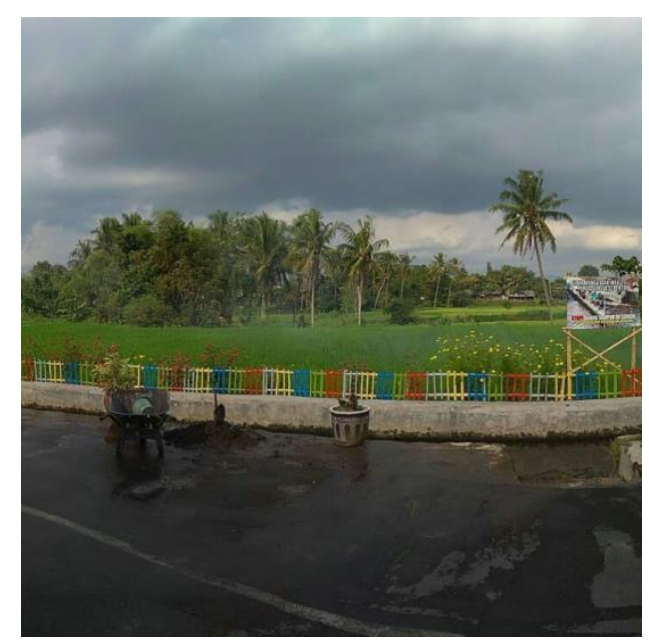

5a) Kondisi jalan utama dusun

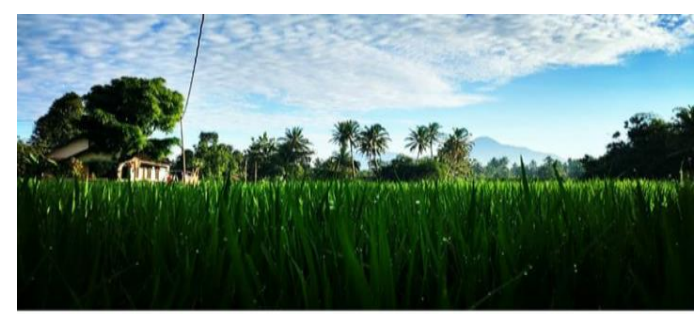

5c) Pemandangan sawah yang asri dan bersih

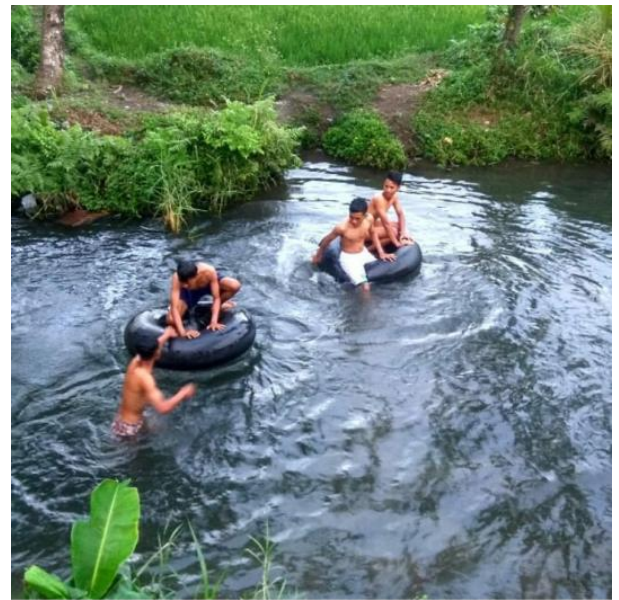

5b) "Kalen" yang tidak lagi kotor dan dapat digunakan untuk aktivitas bermain anak-anak

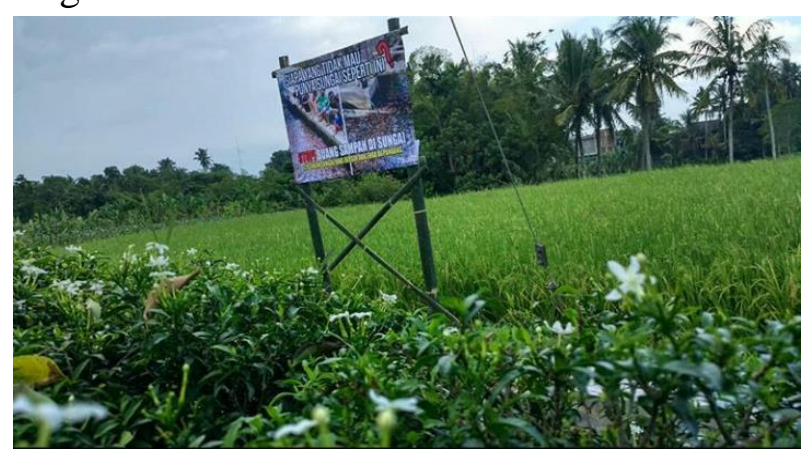

5d) Banner peduli lingkungan di salah satu sudut "Kampoeng Kalen"

Gambar 5. Kondisi desa wisata "Kampoeng Kalen” saat ini

\section{Simpulan dan Saran}

\section{Kesimpulan}

Pengembangan Desa Wisata "Kampoeng Kalen" telah dilaksanakan melalui partisipasi warga terutama para pemuda melalui Generasi Muda-mudi Danen (GMD) dan Remaja Masjid Al Furqon (REMAF). GMD dan REMAF dapat menjadi agen dalam menanamkan sikap pro-lingkungan masyarakat. Sikap pro-lingkungan masyarakat sudah mulai terbentuk ditandai dengan telah berkurangnya warga yang membuang sampah dan menebang pohon sembarangan serta dari lingkungan dusun yang semakin asri.

Saran yang dapat disampaikan yaitu agar kegiatan pengembangan "Kampoeng Kalen" dapat terus dilaksanakan dengan partisipasi aktif seluruh warga dusun Danen. Masyarakat harus semakin peduli dengan keadaan lingkungan di sekitarnya.

\section{Rekomendasi}

Rekomendasi penulis sampaikan kepada: 
1. Jajaran perangkat desa Sumberadi dusun Danen untuk selalu mendampingi dan mendukung pelaksanaan pengembangan desa wisata "Kampoeng Kalen".

2. Kementerian Pariwisata melalui pemerintah Kabupaten Sleman dapat memberikan izin dan mengesahkan Pokdarwis dusun Danen yang telah dibentuk serta memberikan dukungan baik material mau pun softskill.

\section{Ucapan Terima kasih}

Ucapan terimakasih disampaikan kepada : 1) Direktorat Riset dan Pengabdian Masyarakat (DRPM) Dirjen DIKTI yang telah mendanai program, 2) Universitas Sarjanawiyata Tamansiswa melalui Lembaga Penelitian, Pengembangan, dan Pengabdian kepada Masyarakat (LP3M) yang selalu mendukung kegiatan, 3) Universitas Muhammadiyah Semarang selaku mitra dan tim kegiatan, 4) Kepala desa, perangkat desa, ketua RW, dan RT di dusun Danen yang telah memberikan izin pelaksanaan program, 5) Para pemuda Danen yang tergabung dalam GMD dan REMAF yang telah bersemangat menyambut, melaksanakan kegiatan pengembangan desa, 6) Seluruh masyarakat dusun Danen yang ikut terlibat dalam kegiatan , 7) Mahasiswa-mahasiswa kami yang ikut terlibat membantu kegiatan, serta semua pihak yang tidak dapat kami sebutkan satu persatu. Semoga program pengembangan desa wisata kampoeng kalen sebagai salah satu bentuk kegiatan pengabdian masyarakat ini dapat bermanfaat.

\section{Daftar Pustaka}

Schultz, P., \& Zelezny, L. (1999). Values as predictors of environmental attitudes: evidence for consistency across 14 countries.
Scott, D., \& Willits, F. K. (1994). Environmental attitudes and behavior: A Pennsylvania survey. Environment and behavior, 26(2), 239-260.

Poortinga, W., Steg, L., \& Vlek, C. (2004). Values, environmental concern, and environmental behavior: A study into household energy use. Environment and behavior, 36(1), 70-93.

Buckley, R. (1994). A framework for ecotourism. Annals of tourism research, 21(3), 661-665.

Kaiser, F. G., Wölfing, S., \& Fuhrer, U. (1999). Environmental attitude and ecological behaviour. Journal of environmental psychology, 19(1), 119.

Powell, R. B., \& Ham, S. H. (2008). Can ecotourism interpretation really lead to pro-conservation knowledge, attitudes and behaviour? Evidence from the Galapagos Islands. Journal of sustainable tourism, 16(4), 467489.

Chiu, Y. T. H., Lee, W. I., \& Chen, T. H. (2014). Environmentally responsible behavior in ecotourism: Antecedents and implications. Tourism management, 40, 321-329.

Beaumont, N. (2001). Ecotourism and the conservation ethic: Recruiting the uninitiated or preaching to the converted?. Journal of Sustainable Tourism, 9(4), 317-341.

Damayanti, E. (2014). Strategi Capacity Building Pemerintah Desa dalam Pengembangan Potensi Ekowisata Berbasis Masyarakat Lokal (Studi di Kampoeng Ekowisata, Desa Bendosari, Kecamatan Pujon, 
Kabupaten Malang). Jurnal

Administrasi Publik, 2(3), 464-470.

Raharjana, D. T. (2012). Membangun pariwisata bersama rakyat.

Dewi, M. H. U. (2013). Pengembangan desa wisata berbasis partisipasi masyarakat lokal di Desa Wisata Jatiluwih Tabanan, Bali. Jurnal Kawistara, 3(2). 